\title{
Serological response of leprosy patients to Mycobacterium leprae specific and mycobacteria specific antigens: possibility of using these assays in combinations
}

\author{
B. SEKAR, R. N. SHARMA, G. LEELABAI, \\ D. ANANDAN, B. VASANTHI, G. YUSUFF, \\ M. SUBRAMANIAN \& M. JAYASHEELA \\ Laboratory Division, Clinical Division and Epidemiology and \\ Statistics Division, Central Leprosy Teaching and Research Insti- \\ tute, Chengalpattu-603001, Tamil Nadu, India
}

\section{Accepted for publication 23 October 1992}

\begin{abstract}
Summary The serological response of 147 leprosy patients to 3 mycobacterial antigens, PGL-I, $35 \mathrm{kDa}$ (Mycobacterium leprae-specific) and LAM (which is a common mycobacterial antigen) were analysed. A stronger serological response was seen amongst the MB patients than the PB patients in all the assays. The 3 antibody levels correlated positively with each other in both $\mathrm{MB}$ and $\mathrm{PB}$ cases. An overlap of seropositivity was seen between anti-PGL-I and anti-LAM $(p>0 \cdot 05)$. A progressive increase in seropositivity and a significant difference of absorbance or titre in antibody levels in all 3 assays over increasing grades of BI were seen in the MB patients $(p<0 \cdot 05)$. A signficant difference in seropositivity between untreated and treated groups of patients was observed for anti PGL-I $(p<0 \cdot 05)$ and antiLAM $(p<0 \cdot 01)$ antibodies. The sensitivity, specificity and efficiency of antiPGL-I (50\%; 99\%; 70\%), antiLAM (43\%; 95\%; 64\%) and anti35 kDa $(66 \%$; $100 \% ; 80 \%$ ) assays taken individually were less than that of combinations of antiPGL-I/anti-35 kDa (74\%; 99\%; 84\%) or antiPGL-I/anti-35 kDa/antiLAM $(80 \% ; 94 \% ; 86 \%)$. The difference in the efficiency of both sets of combination of assays were not statistically significant $(p>0 \cdot 05)$.
\end{abstract}

\section{Introduction}

In recent years the serological response of leprosy patients to different mycobacterial antigens has been studied. Species-specific capsular phenolic glycolipid-I (PGL-I), ${ }^{1,2}$ protein antigens like $35 \mathrm{kDa}^{3} 36 \mathrm{kDa}^{4}$ and $18 \mathrm{kDa}^{5}$ of Mycobacterium leprae and common mycobacterial antigens like lipoarabinomannan (LAM), ${ }^{6}$ a potent B cell stimulator, have been used in enzyme-immunoassays to study serological response 
amongst leprosy patients. Strong serological responses to these antigens have been shown in the lepromatous (LL) pole of the spectrum and a weaker response in the tuberculoid (TT) pole. These studies were carried out in a mixed group of treated and untreated ${ }^{2,4,7-12}$ and also selectively in untreated patients ${ }^{13}$ of multibacillary (MB) leprosy. Such studies have also been done in paucibacillary (PB) leprosy. ${ }^{3,7,14-17}$ Here, a cross-sectional study involving both $\mathrm{MB}$ and $\mathrm{PB}$ leprosy patients has been carried out to analyse: (a) the serological response of both $\mathrm{MB}$ and $\mathrm{PB}$ patients to $2 \mathrm{M}$. leprae specific antigens (PGL-I and $35-\mathrm{kDa}$ ) and a common mycobacterial antigen (LAM); (b) the correlation of the antibody levels with the bacterial index (BI) in MB patients; (c) the association of the antibody levels with treatment status; (d) the efficiency of 3 assays individually and in combination.

\section{Materials and methods}

A total of 147 leprosy patients attending CLT \& RI were included in this study, comprising of 91 lepromatous (LL), 10 borderline lepromatous (BL), 26 tuberculoidborderline (TT-BT) and 20 indeterminate (IND) leprosy cases, all who had been clinically diagnosed. They consisted of both untreated and treated patients. In addition, 100 healthy subjects working in different departments of CLT \& RI were included in the study as controls. Sera from all patients and controls were collected and stored at $-20^{\circ} \mathrm{C}$ until used.

A routine slit-skin smear was done for all leprosy patients and the average BI was calculated according to the Ridley's scale.

SEROLOGICAL ASSAYS

\section{AntiPGL-I ELISA}

IgM antiPGL-I antibodies were measured by using the procedure reported earlier. ${ }^{18}$ Briefly D-BSA antigen and BSA supplied by IMMLEP/WHO, diluted in carbonatebicarbonate buffer $(\mathrm{CBCB})$ were coated in duplicate in a 96-well flat bottom microtitre plate (Dynatec Micro-ELISA system, Germany). Sera at 1:300 dilution were added to both antigen and BSA coated wells. After incubation, antihuman IgM peroxidase conjugate (DAKO, Denmark) was added at 1:2000 dilution. Colour was developed with $o$-phenylenediamine (SIGMA, USA) with $\mathrm{H}_{2} \mathrm{O}_{2}$ in citrate-phosphate buffer, $\mathrm{pH} \mathrm{5 \cdot 0.} \mathrm{The}$ reaction was stopped with $5 \mathrm{NH}_{2} \mathrm{SO}_{4}$. The plates were read at $492 \mathrm{~nm}$ in an ELISA reader (MR 600 micro plate reader, Dynatec). Samples with a difference in the mean absorbance between the antigen and BSA coated wells equal to or more than 0.200 OD were considered positive.

\section{Serum Antibody Competition Test-ELISA (SACT-E)}

Antibodies to the $M$. leprae specific $35-\mathrm{kDa}$ protein were detected by the protocol of $\mathrm{J}$. Ivanyi, using peroxidase conjugated ML-04 monoclonal antibody (kindly supplied by J. Ivanyi, MRC, the Royal Postgraduate Medical School, London). Microtitre plates (Immulon, M129 B Dynatec) were coated with $10 \mu \mathrm{g} / \mathrm{ml}(50 \mu \mathrm{l} /$ well) of $M$. leprae soluble 
extract (kindly supplied by R. J. W. Rees, IMMLEP M. leprae bank) in phosphatebuffered saline (PBS), pH 7·2, and incubated overnight at $4{ }^{\circ} \mathrm{C}$. After washing once with Tris-buffered saline, $\mathrm{pH} 7 \cdot 4$, containing Tween 20 (TBST), blocking was done with $150 \mu \mathrm{l} /$ well of $1 \%$ skimmed milk powder in TBST (TBSTM). Sera in 10-fold dilution of $1: 10$, $1: 100$ and $1: 1000$ in TBSTM $(25 \mu \mathrm{l} /$ well $)$ were added in duplicate and incubated for $1 \mathrm{hr}$. After removing the sera, $25 \mu \mathrm{l}$ /well of appropriately diluted peroxidase conjugated ML-04 was added and incubated for $2 \mathrm{hr}$. After washing with TBST, colour was developed with $o$-phenylenediamine substrate solution $(50 \mu \mathrm{l} /$ well for $20 \mathrm{~min}$ ). The reaction was stopped with $5 \mathrm{NH}_{2} \mathrm{SO}_{4}$ and reading was done at $492 \mathrm{~nm}$ in an ELISA reader. Positive control wells incubated with ML-04 conjugate without inhibiting sera were included in all the plates.

The dilution of the sera causing 50\% inhibition of binding of ML-04 to the antigen $\left(\mathrm{ID}_{50}\right)$ was calculated. Samples with $\mathrm{ID}_{50}$ titres equal to or more than 10 were considered SACT-E positive. All the 100 control sera tested were SACT-E negative.

\section{AntiLAM ELISA}

IgG antiLAM antibodies were measured by coating with LAM from $M$. tuberculosis H37Ra (kindly supplied by D. Chatterjee, Colorado State University, Fort Collins, Colorado, USA) at a concentration of $1 \mu \mathrm{g} / \mathrm{ml}$, diluted in $\mathrm{CBCB}, \mathrm{pH} 9.6$ in duplicate. Control wells were coated with buffer $(\mathrm{CBCB})$ alone. Sera at a dilution of 1:1000 were added $(50 \mu \mathrm{l} /$ well) to both antigen and control wells. After incubation for $2 \mathrm{hr}$, antihuman IgG peroxidase conjugate (DAKO, Denmark) at 1:6000 dilution was added. $O$ phenylenediamine with $\mathrm{H}_{2} \mathrm{O}_{2}$ in phosphate citrate buffer, $\mathrm{pH} 5 \cdot 0$, was used as a substrate solution. The reaction was stopped with $5 \mathrm{NH}_{2} \mathrm{SO}_{4}$ and plates were read at $492 \mathrm{~nm}$ in an ELISA reader. Samples with a difference in the mean absorbance between the antigen and control wells equal to or more than 0.500 OD (mean +3 standard deviations of 100 controls) were considered positive.

\section{STATISTICAL ANALYSIS}

The Mantel-Haenzsel Chi-squared method (cases, control as strata) was used to study the significance of differences between the antibody assays. The coefficients of correlation among 3 assays and between each assay and BI in individual patients were determined by Pearson's correlation coefficient. The Mann-Whitney $U$ test was done for the differences in the distribution of absorbances or titre between the different BI groups. The KrushkalWallis test was applied when more than 2 groups were compared. The significance of differences of seropositivity between $\mathrm{MB}$ and $\mathrm{PB}$ groups and between smear positive and smear negative MB cases were derived from $2 \times 2$ contingency tables by applying Yate's corrected Chi-squared test. Probability $(p)$ values $<0.05$ were considered as significant.

All the statistical tests were carried out using SSPS/PC + and EPI-INFO software packages.

\section{Results}

SEROLOGICAL RESPONSE

The serological response among the MB group of patients was found to be uniformly 
Table 1. Serological response of both $\mathrm{MB}$ and PB leprosy patients to 3 mycobacterial antigens.

\begin{tabular}{|c|c|c|c|c|}
\hline & \multicolumn{4}{|c|}{$\begin{array}{c}\text { Percentage of seropositive } \\
\text { (absolute number in parentheses) }\end{array}$} \\
\hline & PGL & LAM & $35 \mathrm{kDa}$ & $\begin{array}{l}\text { Any of } 3 \\
\text { antibodies }\end{array}$ \\
\hline \multicolumn{5}{|l|}{ Patients (N) } \\
\hline MB (101) & $58(59)$ & $44(44)$ & $90(91)$ & $93(94)$ \\
\hline LL (50) BI (+) & $74(37)$ & $52(26)$ & $100(50)$ & $100(50)$ \\
\hline LL (41) BI (-) & 34 (14) & $24(10)$ & $76(31)$ & $83(34)$ \\
\hline $\mathrm{BL}(10) \mathrm{BI}(+)$ & $80(08)$ & $80(08)$ & $100(10)$ & $100(10)$ \\
\hline PB (46) & $33(15)$ & 41 (19) & $13(06)$ & $52(24)$ \\
\hline TT-BT (26) & $27(07)$ & $35(09)$ & $12(03)$ & $46(12)$ \\
\hline IND (20) & $40(08)$ & $50(10)$ & $15(03)$ & $60(12)$ \\
\hline Control (100) & $1(01)$ & $5(05)$ & $0 \quad(0)$ & $6(06)$ \\
\hline Sensitivity & 50 & 43 & 66 & 80 \\
\hline Specificity & 99 & 95 & 100 & 94 \\
\hline
\end{tabular}

Significant difference of seropositivity of IgM antiPGL-I and anti35 kDa antibodies between MB and PB patients $(p<0 \cdot 01)$.

Significant difference of seropositivity of IgM antiPGL-I and IgG antiLAM and anti35 $\mathrm{kDa}$ antibodies between smear positive and smear negative $\mathrm{MB}$ cases $(p<0.001)$.

Significant difference of seropositivity between antiPGL-1 and $35 \mathrm{kDa}$ in total $(p<0 \cdot 05)$.

No significant difference of seropositivity between antiPGL-1 and antiLAM in total $(p>0 \cdot 05)$.

higher than on the PB group of patients (Table 1). In MB cases, 58\% had IgM antiPGL antibodies, $44 \%$ antiLAM antibodies and $90 \%$ anti35 $\mathrm{kDa}$ antibodies; $93 \%$ of patients in the $\mathrm{MB}$ group had any of the 3 antibodies. In the PB cases, $33 \%$ had antiPGL antibodies, $41 \%$ antiLAM antibodies and $13 \%$ anti35 $\mathrm{kDa}$ antibodies; $52 \%$ of patients in the PB group had any of the 3 antibodies. In the MB group, smear positive patients had a higher percentage of seropositivity (antiPGL-I, 75\%; antiLAM, 57\%; anti35 kDa, 100\%) compared with smear negative (antiPGL-I, 34\%; antiLAM, 24\%; anti35 kDa, 76\%) patients. In general, the $35 \mathrm{kDa}$ antigen was found to elicit a serological response in a higher proportion of different types of the MB patients compared to the other 2 antigens. Within the PB group, apparently a higher percentage (antiPGL-I, 40\%; antiLAM, 50\%; anti35 kDa, $15 \%$ ) of IND type patients showed a serological response to all the 3 antigens compared to the TT-BT patients (antiPGL-I, 27\%; antiLAM, 35\%; anti35 kDa, 12\%).

Out of 100 controls employed in the study $1 \%$ had antiPGL-I antibodies, 5\% antiLAM antibodies and none had anti35 $\mathrm{kDa}$ antibodies.

\section{ASSOCIATION WITH BI}

Of the $101 \mathrm{MB}$ cases studied, 60 were smear positive with a $\mathrm{BI}$ ranging from $0 \cdot 16$ to $3 \cdot 67$. 
Table 2. Relationship between serological responses to 3 mycobacterial antigens and $\mathrm{BI}$ in $\mathrm{MB}$ leprosy patients (\% seropositive (mean absorbance/ titre)).

\begin{tabular}{lcccc}
\hline $\begin{array}{l}\text { Bacterial } \\
\text { index }\end{array}$ & $\begin{array}{c}\text { No. } \\
\text { patients }\end{array}$ & \multicolumn{1}{c}{ PGL } & LAM & $35 \mathrm{kDa}$ \\
\hline Negative & 41 & $34 \%(0 \cdot 462)$ & $24 \%(0 \cdot 855)$ & $76 \%(174 \cdot 5)$ \\
$<1$ & 20 & $65 \% *(0 \cdot 622)$ & $45 \% *(0 \cdot 913)$ & $100 \% *(223 \cdot 9)$ \\
$>=1$ to $<2$ & 21 & $76 \% *(0 \cdot 514)$ & $52 \% *(0 \cdot 946)$ & $100 \% *(284 \cdot 4)$ \\
$>=2$ & 19 & $84 \% *(0 \cdot 579)$ & $74 \% *(1 \cdot 032)$ & $100 \% *(673 \cdot 6)$ \\
\hline
\end{tabular}

* Significant differences in the distribution of absorbance (or) titres of antibodies with BI positive group compared to BI negative group (MannWhitney, $p<0.05$ ).

The increase in the absorbances (or) titres over the range of $\mathrm{BI}$ was significant for all the 3 antibody assays $(p<0.001)$ by Krushkal-Wallis analysis.

All the 3 assays showed progressive increase of seropositivity with an increase in BI. Such a trend was also observed in mean antibody titres (Table 2). All the 3 levels of the antibodies positively correlated with $\mathrm{BI}$ (anti35 kDa $v$ BI, $r=0 \cdot 4638, p<0 \cdot 001$; antiPGLI $v s \mathrm{BI}, r=0.3119, p<0 \cdot 01$; and antiLAM $v s \mathrm{BI}, r=0 \cdot 3689, p<0 \cdot 001)$.

\section{ASSOCIATION WITH THE TREATMENT STATUS}

The multibacillary group consisted of 19 untreated and 82 treated cases. Amongst untreated cases, $84 \%$ had antiPGL-I antibodies, $88 \%$ antiLAM antibodies and 100\% anti35 kDa antibodies. Amongst treated cases 52\% had antiPGL-I antibodies, 38\% antiLAM antibodies and $88 \%$ anti35 $\mathrm{kDa}$ antibodies (Table 3). The paucibacillary group consisted of 30 untreated and 16 treated cases. Amongst untreated cases $43 \%$ had antiPGL-I antibodies, 57\% antiLAM antibodies and 13\% anti35 kDa antibodies. Amongst treated cases $13 \%$ had antiPGL-I antibodies, and the same percentage of cases were also positive for the other 2 assays. Though the untreated cases had a higher percentage of seropositivity in all the 3 assays than did the treated, the differences were significant for antiPGL-I $(p<0.05)$ and antiLAM $(p<0.01)$ assays but not for the anti35kDa assay $(p>0.05)$.

\section{CORRELATION BETWEEN THE ANTIBODY ASSAYS}

In the MB group, all the 3 assays positively correlated with each other. There was a strong correlation between antiPGL-I and antiLAM antibodies $(r=0.5048, p<0 \cdot 001)$ and also between antiPGL-I and anti35kDa antibodies $(r=0.3917, p<0.001)$. A moderate correlation was seen between antiLAM and anti-35kDa antibodies $(r=0 \cdot 3172, p<0 \cdot 01)$.

In the PB group, a moderate positive correlation between the assays was observed (antiPGL-I vs anti-35 kDa, $r=0.4385, p<0.01$; antiPGL-I $v s$ antiLAM, $r=0.3495$, $p<0.05$ and antiLAM $v s$ anti35 $\mathrm{kDa}, r=0.4183, p<0.01)$.

Multibacillary patients with antiPGL-I antibodies were also more likely to have antiLAM antibodies ( $p>0.05)$, but such an overlap was not seen between anti35 kDa and 
Table 3. Serological responses to 3 mycobacterial antigens in untreated and treated groups of patients.

\begin{tabular}{|c|c|c|c|c|}
\hline Patients & $\begin{array}{l}\text { Treatment } \\
\text { status }\end{array}$ & PGL & LAM & $35 \mathrm{kDa}$ \\
\hline \multirow[t]{2}{*}{ MB (101) } & UNT (19) & $84 \% \quad(16)$ & $88 \% \quad(14)$ & $100 \% \quad(19)$ \\
\hline & TRT (82) & $52 \% *(43)$ & $38 \%+(31)$ & $88 \% \ddagger(72)$ \\
\hline \multirow[t]{2}{*}{ PB (46) } & UNT (30) & $43 \% \quad(13)$ & $57 \%$ & $13 \%$ \\
\hline & TRT (16) & $13 \%$ & $13 \% \quad(02)$ & $13 \% \quad(02)$ \\
\hline
\end{tabular}

* Differences in seropositivity of antiPGL between treated and untreated groups $(p<0 \cdot 05)$.

$\dagger$ Differences in seropositivity of antiLAM between treated and untreated groups $(p<0.01)$.

$\ddagger$ Differences in seropositivity of anti35 kDa between treated and untreated groups $(p>0 \cdot 05)$

UNT, untreated; TRT, Treated.

the other 2 antibodies. In the PB group as well, an overlap of seropositivity was only seen between anti-PGL-I and anti-LAM antibodies ( $p>0.05)$. The seropositivity for any of the antibodies, when taken in combinations like antiPGL-I/antiLAM, antiPGL-I/anti35 $\mathrm{kDa}$, or antiPGL-I/anti35 kDa/antiLAM, showed sensitivity and specificity higher than the corresponding assays taken individually (Figure 1). Thus, when the seropositivity for any of the 2 assays using the $M$. leprae specific antigens, namely, PGL-I and $35 \mathrm{kDa}$, were taken together, the combined sensitivity $(74 \%)$ and specificity $(99 \%)$, and thereby the

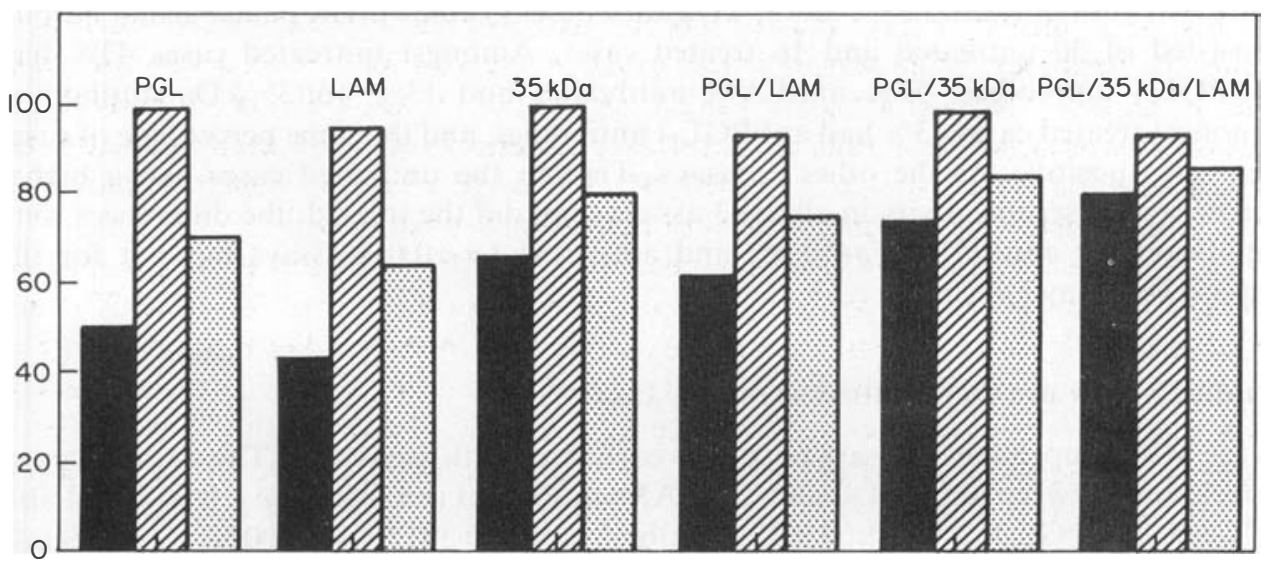

Figure 1. Sensitivity, specificity and efficiency of the assays, alone and in combinations. $\mathbf{\square}$, sensitivity; $\square$, specificity; 娄, efficiency.* Difference of seropositivity between combinations of antiPGL-I/anti-35 kDa and antiPGL-I/antiLAM $(p>0.05)$; difference of seropositivity between combinations of antiPGL-I/anti-LAM and antiPGL-I/anti-LAM/anti35 kDa $(p<0 \cdot 01)$; difference of seropositivity between combinations of antiPGL-I/ anti-35 kDa and antiPGL-I/antiLAM/anti35 kDa $(p>0.05)$.

$*$ Efficiency (index of usefulness) $=\frac{\text { No. of true positives }+ \text { No. of true negatives }}{\text { Total no. of subjects studied }}$ 
efficiency (84\%), was higher. Similarly, when the seropositivity for any of the 3 assays, using both the species specific (PGL-I and $35 \mathrm{kDa}$ ) and the genus specific (LAM) antigens was taken together, the combined sensitivity $(80 \%)$ and efficiency $(86 \%)$ was even higher, though there was a decline in specificity $(94 \%)$. Yet the utility of both the sets of combination assays was comparable $(p>0.05)$.

\section{Discussion}

Many mycobacteria-specific and $M$. leprae-specific antibodies have been demonstrated in the sera of leprosy patients. Though they are not known to be protective, their presence in the sera of leprosy patients may be used as markers of bacillary load, monitors of prognosis of the disease and predictors of occurrence of future relapse or reactions. Several studies have been done against this background. ${ }^{7-14,16,17,19}$ In the present study, a cross-sectional analysis of 147 leprosy patients showed a stronger serological response in the MB group of patients than the PB group to all the 3 antibodies, but significantly to both $M$. leprae-specific antigens (PGL-I and $35-\mathrm{kDa}$ ). The response to $35 \mathrm{kDa}$ antigen was higher in both smear-positive and smear-negative MB patients, with sensitivity being greater than in the other 2 assays. These findings are consistent with the observations of other researchers. ${ }^{12.13 .16 .17 .19}$ In the PB group the sensitivity of $35 \mathrm{kDa}$ was less, though others have shown higher sensitivity. ${ }^{16,17}$ However, all the 3 assays, when individually analysed, had a higher specificity with considerably lower sensitivity.

All the 3 antibodies studied correlated positively with each other, both in the MB and the PB cases. Further, an overlapping of positivity was seen only between antiPGL-I and antiLAM antibodies, but not between anti35 $\mathrm{kDa}$ and other antibodies. Thus, this specific $35 \mathrm{kDa}$ epitope of $M$. leprae was observed to pick up, at least in the MB group, those leprosy patients who were negative for antibodies against the other 2 antigens.

All the 3 antibody assays showed a progressive increase of seropositivity and mean antibody titres over the increasing grades of BI, all the 3 antibodies positively correlated with BI as well. This correlation was highly significant for anti-35 kDa antibody. Thus, this positive association of antibody titres with bacterial load can be used to monitor the prognosis of patients in conjunction with BI. Hence, these assays would be complementary to BI in detecting additional cases of multibacillary patients. ${ }^{13}$

Both in the MB and the PB groups, the seropositivity among untreated patients was higher than in the treated patients. This difference was significant for antiPGL-I and antiLAM antibodies only. But a relatively steep fall in the anti35 kDa antibody titre with least individual variability on treatment has been observed by others. ${ }^{19}$ Thus the antibody assays would seem to supplement the clinical evaluation in assessing the prognosis of patients on chemotherapy. Further prospective studies may throw some more light on this observation.

Amongst the PB group, 'IND' type patients showed apparently high seropositivity for all the 3 antibodies in comparison to 'TT-BT' type. This might suggest that most 'IND' leprosy patients are likely to progress to the MB type of leprosy, as has been observed by other reporters. $^{21}$

An assay using lipoarabinomannan of $M$. tuberculosis was used in this study because of its similarity with the LAM of $M$. leprae. ${ }^{22}$ Despite not being species-specific this antigen appears to be useful in the serology of leprosy. The sensitivity of this assay is 
comparable to that of antiPGL-I assay. Further, this assay could differentiate between smear positive and smear negative $\mathrm{MB}$ cases and also between treated and untreated cases like antiPGL-I assay. AntiLAM antibodies correlated positively with $M$. leprae-specific antibodies in MB and PB cases. AntiLAM assay, when combined with other assays, increased the efficiency in both antiPGL-I/antiLAM and antiPGL-I/antiLAM/anti35 $\mathrm{kDa}$ combinations. Hence the value of antiLAM assay in leprosy serology.

Thus this analysis on the serological responses of leprosy patients to $M$. leprae-specific (PGL-I and $35 \mathrm{kDa}$ ) and a genus specific antigen (LAM) revealed that these antibody assays are complementary to clinical evaluation of leprosy patients. This was evidenced by a strong immunological response amongst leprosy patients to the 3 antigens, significant correlation with BI and with the treatment status of the patients. The assays, though individually highly specific, were less sensitive. This could be compensated by analysing the seropositivity for any of $2 M$. leprae-specific antibodies (antiPGL-I/anti35 $\mathrm{kDa}$ ) or any of the 3 antibodies (antiPGL-I/anti35 $\mathrm{kDa} /$ antiLAM) in combinations. In this way we obtain an improved application of the serological assays in the management of leprosy patients, until an antigen which is highly sensitive in detecting both MB and PB cases equally is developed.

\section{Acknowledgment}

We thank IMMLEP/WHO for the supply of D-BSA antigen; Dr R. J. W. Rees for the provision of $M$. leprae soluble extract through IMMLEP/WHO/UNDP/World Bank Tropical Disease Research Programme; Professor J. Ivanyi for providing ML-04 conjugate; and Dr D. Chatterjee for supplying LAM antigen. We give sincere thanks to Mr L. Rathinavel and Mr K. Kuberan, Laboratory Division, CLT \& RI, for their dedicated technical assistance, and we thank Dr P. Krishnamoorthy, Epidemiology and Statistics Division, CLT \& RI for the assistance in statistical analysis and Dr N. Elangeswaran, Laboratory Division, Dr A. V. Paul, Clinical Division and Dr P. S. Rao, Director-In-Charge of CLT \& RI for their encouragement.

\section{References}

1 Young DB, Buchanan TM. A serological test for leprosy with a glycolipid specific for Mycobacterium leprae. Science, 1983; 221: 1057.

2 Brett SJ, Draper P, Payne SN, Rees RJW. Serological activity of a characteristic phenolic glycolipid from $M$. leprae in sera from patients with leprosy and tuberculosis. Clin Exp Immunol, 1983; 52: 271-279.

${ }^{3}$ Sinha S, Sengupta U, Rumu G, Ivanyi J. Serological survey of leprosy and control subjects by a monoclonal antibody based immunoassay. Int J Lepr, 1985; 53: 33-38.

4 Klatser PR, de Wit MYL, Kolk AHJ. An ELISA-inhibition test using monoclonal antibody for serology of leprosy. Clin Exp Immunol, 1985; 58: 468-473.

5 Britton WJ, Hellqvist L, Basten A, Raison RL. Mycobacterium-leprae antigens involved in human immune responses. 1. Identification of four antigens by monoclonal antibodies. J Immunol, 1985; 135: 4171-4177.

6 Miller RA, Dissanayake S, Buchanan TM. Development of an enzyme-linked immunosorbent assay using arabinomannan from Mycobacterium smegmatis: A potentially useful screening test for the diagnosis of incubating leprosy. Am J Trop Med, 1983; 32: 555-564.

7 Bach MA, Wallach D, Flageul B, Hoffenbach A, Cottenot F. Antibodies to phenolic glycolipid-I and to whole Mycobacterium leprae in leprosy patients; evolution during therapy. Int J Lepr, 1986; 54: 256-267.

8 Cho SN, Yanagihara DL, Hunter SW, Gelber RH, Brennan PJ. Serological specificity of phenolic glycolipidI from Mycobacterium leprae and use in serodiagnosis of leprosy. Inf Immun, 1983; 41: 1077-1083. 
9 Levis WR, Meeker HC, Schuller-Levis GB, Sersen E, Brennan PJ, Fried P. Mycobacterial carbohydrate antigens for serological testing of patients with leprosy. J. Infect Dis 1987; 56: 763-769.

${ }^{10}$ Lyons NF, Shannon EJ, Ellis BPB, Naffs B. Association of IgG and IgM antibodies to phenolic glycolipid antigen of $M$. leprae with disease parameters in multibacillary leprosy patients. Lepr Rev, 1988; 59: 45-52.

11 Meeker HC, Levis WR, Sersen E, Schuller-Levis G, Brennan PJ, Buchannan TM. ELISA detection of IgM antibodies against phenolic glycolipid-I in the management of leprosy, a comparison between laboratories. Int J Lep 1986; 54: 530-539.

12 Mwatha J, Moreno C, Sengupta U, Sinha S, Ivanyi J. A comparative evaluation of serological assay of lepromatous leprosy. Lepr Rev, 1988; 59: 195-199.

13 Roche PW, Britton WJ, Failbus SS, Williams D, Pradhan HM, Theuvenet WJ. Operational value of serological measurement in multibacillary patients. Clinical and bacteriological correlates of antibody responses. Int J Lep, 1990; 58: 480-490.

14 Touw JML, Diepen TW, Harboe M, Belehu A. Relationship between anti-mycobacterium leprae antibody activity and clinical features in borderline tuberculoid (BT) leprosy. Int J Lep, 1983; 51(3): 305-311.

15 Harboe M, Closs O, Reiton LJ, Draper P. Demonstration of antibodies reacting with different determinants on Mycobacterium leprae antigen 7. Int J Lep, 1981; 49: 147-158.

16 Roche PW, Britton WJ, Failbus SS, Theuvent WJ, Adiga RB. Heterogeneity of serological responses in paucibacillary leprosy-differential responses to protein and carbohydrate antigens and correlation with clinical parameters. Int J Lep, 1990; 58: 319-327.

17 Chaturvedi V, Sinha S, Giridhar BK, Katoch K, Bhatia AS, Sengupta U. Association of mycobacteria specific and Mycobacterium leprae specific antibody levels with clinical activity in tuberculoid leprosy; A comparative study of three serological enzyme immunoassays. Lep Rev, 1991; 62: 122-133.

18 Dhandayuthapani S, Anandan D, Vasanthi P, Bhatia VN. Use of eluates of filter paper blood spots in ELISA for the serodiagnosis of leprosy. Ind J Med Res, 1989; May: 150.

19 Chaturvedi V, Sinha S, Giridhar BK, Sengupta U. On value of sequential serology with a mycobacterium leprae-specific antibody competition ELISA in monitoring leprosy chemotherapy. Int J Lep, 1991; 59: 32-40.

20 Klatser PR, de Wit MYL, Fajardo TT, Cellona RV, Abalos RM, de la Cruz EC, Madarang MG, Hirsch DS, Douglas JT. Evaluation of Mycobacterium leprae antigens in the monitoring of a dapsone-based chemotherapy of previously untreated lepromatous patients in Cebu, Philippines. Lep Rev, 1989; 60: 178186.

21 Takhashi MD, Andrade Jr HF, Wakamatsu H, Siqueira S, de Britto T. Indeterminate leprosy; Histopathological and histochemical predictive parameters involved in its possible change to paucibacillary (or) multibacillary leprosy. Int J Lep, 1991; 59: 12-19.

22 Gaylord H, Brennan PJ, Leprosy and leprae bacillus; present development in characterisation of antigens and immunology of the disease. Ann Rev Microbial, 1987; 41: 645-675. 


\title{
Réponse sérologique des patients lépreux aux antigènes spécifiques de mycobacterium leprae et spécifiques des mycobactéries: possibilité d'utiliser ces essais en association
}

\author{
B. Sekar, R. N. Sharma, G. Leelabai, D. Anandan, B. Vasanthi, \\ G. Yusuff, M. Subramanian et M. Jayasheela
}

\begin{abstract}
Résumé Nous avons analysé la réponse sérologique de 147 patients lépreux à 3 antigènes mycobactériens, PGL-I, 35 kDA (spécifique de Mycobacterium leprae) et LAM (qui est un antigène mycobactérien commun). Une réponse plus forte a été observée parmi les patients $\mathrm{MB}$ que parmi les patients $\mathrm{PB}$ dans tous les essais. Les taux des 3 anticorps étaient en corrélation positive entre eux à la fois dans les cas MB et PB. Une séropositivité croisée a été observée entre anti-PLG-I et anti-LAM $[p>0,05]$. Une augmentation progressive de la séropositivité et une différence significative entre l'absorption ou le titre des taux d'anticorps dans les 3 essais sur des degrés croissants de BI ont été observés chez les patients $\mathrm{MB}(p<0,05)$. Une différence significative de la séropositivité entre les groupes de patients non-traités et traités a été observée avec les anticorps anti-PLG-I $(p<0,05)$ et anti-LAM $(p<0,01)$. La sensibilité, spécificité et efficacité des essais avec anti-PGL-I $(50 \% ; 99 \%$; $70 \%)$, anti-LAM $(43 \% ; 95 \% ; 64 \%)$ et anti-35 kDA $(66 \% ; 100 \% ; 80 \%)$ pris séparément étaient inférieures à celles des associations anti-PLG-I/anti-35 kDA $(74 \% ; 99 \% ; 84 \%)$ ou anti-PLG-I/anti-35 kDa/anti-LAM (80\%; $94 \% ; 86 \%)$. La différence entre l'efficacité des deux séries d'associations d'essais n'étaite pas statistiquement significative $(p>0,05)$.
\end{abstract}

\section{La respuesta serológica de los pacientes leprosos a antigenos específicos para Mycobacterium leprae y Micobacterias: la posibilidad de usar estos ensayos en combinaciones}

\author{
B. Sekar, R. N. Sharman, G. Leelabai, D. Anandan, B. Vasanthi, \\ G. Yusuff, M. Subramanian y M. Jayasheela
}

\begin{abstract}
Resumen Se analizaron las respuestas serológicas de 147 pacientes leprosos a 3 antigenos micobacterianos, PGL-I, 35 kDa (específico a Mycobacterium leprae) y LAM, un antigeno micobacteriano común. Se observó una respuesta serológica más fuerte entre los pacientes $\mathrm{MB}$ que entre los $\mathrm{PB}$, en todos los ensayos. Los tres niveles de anticuerpo correlacionaban positivamente entre sí, tanto en los casos MB como los PB. Se observó un traslapo en los resultados de seropositividad entre anti-GPL-I y anti-LAM $(p>0,05)$. Se observó un aumento progresivo de seropositividad y una diferencia significativa de absorbancia o titulación de los niveles de anticuerpo en todos los 3 ensayos con crecientes tipos de BI en los pacientes MB $(p<0,05)$. Se observó una diferencia significativa de seropositividad entre los grupos de pacientes sin tratar y tratados con anticuerpos anti-PGL-I $(p<0,05)$ y anti-LAM $(p<0,01)$. La sensibilidad, especificidad y eficiencia de los ensayos anti-PGLI $(50 \% ; 99 \% ; 70 \%)$, anti-LAM $(43 \% ; 95 \% ; 64 \%)$ y anti-35 kDa $(66 \% ; 100 \% ; 80 \%)$ tomados individualmente eran menos que las combinaciones de anti-GPL-I/anti-35 kDa (74\%; 99\%; 84\%) o anti-GPL-I/anti-35 kDa/ anti-LAM $(80 \% ; 94 \% ; 86 \%)$. La diferencia de eficiencia entre ambos juegos de combinación de ensayos no era significativa $(p>0,05)$.
\end{abstract}

